\title{
Avoiding infantile paralysis. Orthopedists and their fight against the sequelae of poliomyelitis in Mexico (1940-1960)
}

\author{
José L. Gómez-De Lara* \\ School of Medicine, Centro Universitario de Ciencias Sociales y Humanidades, Universidad de Guadalajara, Guadalajara, Jalisco, Mexico
}

\begin{abstract}
The objective is to analyze the work of orthopedists during the poliomyelitis epidemic that hit the Mexican population in the mid-forties and early fitties of the twentieth century, who in their eagerness to combat the sequelae that this disease produced, invented all kinds of mechanical means and stabilization of the hips and legs (so that the child could be as independent as possible), such as girdles, corsets, knee pads and wristbands. Others such as wheelchairs, walkers, hinges, and crutches underwent modifications, depending on the needs of the disabled. These advances in the medical field contributed to the development and progress of orthopedics in Mexico. The logical historical method was followed; archives and library documents, periodicals, and other consultation materials such as monthly health bulletins, texts on epidemics, orthopedics, medicine, and medical history were reviewed, as well as files from professors and academics.
\end{abstract}

Key words: Orthopedics. Poliomyelitis. Mexico.

\section{Introduction}

\section{Conjure}

Don't arrive, poliomyelitis to make children cry and make them feel that your hatred wishes to make them ill. Do not afflict a parent and take away their joy, since children around the world must their health enjoy.

Contribution by the students of the "General Vicente

Guerrero."

Educational Unit in their fight against the threat of an epidemic.

Santo Tomas Chautla, Puebla, Pue. 1968.

It was mainly the mothers who were most worried about this disease, fearing their children would develop paralysis for the rest of their lives or, as in most cases, would succumb to the disease. During an epidemic, numerous mothers, anguished and terrorized, would call their pediatrician sure their kid was sick with poliomyelitis. The physician, to make sure the child was sick with polio, asked the mother to perform the following test: if the child was able to kiss their knees, it was a sign that they did not have too much stiffening of the back, nor rigidity of the nape, and thus the mother could calm down. If the child could not kiss their knees, the physician would visit the child to make sure there was something more, since that is a very significant symptom 1 . For this reason, families made their children stay at home as much as possible and remained far from children known to have contracted the disease.

The term poliomyelitis was first used in the year 1873 by the German doctor Adolf Kussma (1822-1902), deriving from the Greek poliós, gray; and myelós, medulla and the suffix itis, inflammation; this way, we can determine that the term poliomyelitis is an infectious and

\section{Correspondence:}

*José L. Gómez-De Lara

E-mail: amoyotl@ @otmail.com
Available online: $18-10-2021$

Date of reception: 02-02-2021

Date of acceptance: 21-06-2021 DOI: 10.24875/RMU.20000088
Medicina Universitaria. 2021;23(3):95-102 www.medicinauniversitaria.org

1665-5796/C 2021 Universidad Autónoma de Nuevo León. Published by Permanyer. This is an open access article under the CC BY-NC-ND license (http://creativecommons.org/licenses/by-nc-nd/4.0/). 
contagious disease caused by three types of virus (type I or Brunhilde, type II or Lansing and type III or Leon ${ }^{2}$ ), causing paralysis of one or several limbs, muscle atrophy and delays of the development of the bones, mainly affecting children under 5 years of age. Originally, it was a condition among children, hence the name infantile paralysis; however, its characteristics have varied, since it has the ability to affect adults as well (the most outstanding case was that of the president of the United States Franklin D. Roosevelt, who contracted poliomyelitis at 39 years old while vacationing at Campobello Island, New Brunswick, Canada). In 1840, Jacob Von Heine (1800-1879), an orthopedist from Stuttgart from a prestigious family of orthopedists who founded one of the first orthopedic institutes in Cannstatt close to Stuttgart, Germany, gave the first clinical description of the disease in his book: Beobachtungen über Lähmungszustände der untern Extremitäten und deren Behandlung (Observations on the stages of lower-limb paralysis and its treatment). The text describes 150 cases of infantile paralysis treated by the orthopedist, differentiating them from other types of paralysis, and describing the deforming injuries of the disease ${ }^{3}$.

Fifty years later, pediatrician Karl Oskar Medin (18471927) described an epidemic in Stockholm, highlighting the infectious characteristics of the disease and its higher incidence among children. He researched 44 cases of poliomyelitis which occurred at the Polyclinic Hospital of Stockholm. For his study, Medin divided the cases into two groups: the spinal type consisted of 27 cases of the paralytic type. The second one was composed of those patients with less common signs based on an uncommon location of the injuries ${ }^{4}$. After several epidemics in different parts of the globe, they began to spread at an alarming rate during the early 1900 s.

Physicians began to acquire the required medical experience after 1940, with the significant change in sanitary and living conditions of the population ${ }^{5}$. However, it was only until 1949, thanks to the work of Doctor Luis Gutierrez Villegas and orthopedist Alejandro Velasco Zimbrón, who isolated the poliomyelitis virus from a patient with acute polio for the $1^{\text {st }}$ time in Mexico, obtaining a virulent strain (type I), that a foundation was set for us to understand the disease better. It was demonstrated that it was a viral disease, which was transmissible, highly contagious, and transmitted by a virus that mainly affected children. Transmission occurs from person to person, and the virus is present in fecal matter, in contaminated water or food. When a person contracted the virus, the contagion time was between
7 and 14 days, ranging from 3 to 35 days. Symptoms included fever and vomiting, a sore throat and headaches, tiredness, rigidity in the neck and back, and pain and rigidity in the legs and arms. Nevertheless, even though it paralyzes the breathing muscles (diaphragm), its main characteristic is paralysis in the acute phase, which occurs in the back, arms, and legs, resulting in muscular atrophy (loss of strength in the muscles of the arms, hands, legs, and feet), and often deformity.

When children did not die during the critical period of the disease, a few remained with the upper and lower limbs paralyzed. To walk, they had to resort to the implementation and use of orthopedic devices. The medical sector was concerned by the reach of the permanent sequelae that this disease caused among its victims and channeled more and more efforts into academic and legislative spaces to put it in a prioritized place in political agendas ${ }^{6}$.

\section{Race against time. Poliomyelitis in Mexico}

In Mexico, the endemic was known since the year 1930, when three cases of poliomyelitis occurred. By 1931, the number of cases increased to six, and again in 1932, while for the year 1934, there was a reduction with just one case. In 1935, five cases were reported, to later disappear momentarily in 1936. In mid-1937, it reappeared with six cases, while in 1938, only three cases were reported. Facing the evidence, in early 1939 , pediatrists in the capital of the country discussed whether infantile paralysis existed in the country or not. Orthopedist Pablo Mendizábal refused to accept the existence of polio in the domestic territory, specifically in the center of the country, since the multiplication of paralytic polio cases was expected, which constituted the evident epidemic state. Given that, it was certain that it did not exist in the country until the year $1946^{7}$, when the presence of the disease was detected when 247 cases occurred (122 cases in Mexico City and 125 in the rest of the country) and with a rising trend. In that year, for the $1^{\text {st }}$ time, the first epidemic manifestations of paralysis were known thanks to the studies conducted by the doctors Pedro Daniel Martinez, Carlos Calderón, and José Bustos Escobedo, who studied the first outbreak of the disease in Orizaba, Veracruz, on May 3, $1946^{8}$.

In Mexico, the oldest case of poliomyelitis recorded is of a male who suffered from the disease in the early years of his childhood in 1912. As an adult, a disability of the locomotive system with characteristics of segmentary paralysis was found, whose background 
corresponded to a case of poliomyelitis. Physician Alfonso Tohen Zamudio mentioned that the disease was already known in an endemic form since 1925. Yet, some researchers have pointed out the existence of paralytic poliomyelitis cases in Mexico in the late $19^{\text {th }}$ century.

To understand epidemics and pandemics, it is important to consider two factors, (1) the movement pattern of individuals, groups, or entire populations, from one area to another and (2) the ways through which the transit of people spreads the disease ${ }^{9}$. If we analyze the cases of poliomyelitis, we can see that the propagation of the disease was linked to migratory movements at the USA-Mexico border. This phenomenon was seen in 1943, a year after the Bracero project was signed.

The regional newspaper "El Siglo de Torreón" on August 25, 1948, published on the front page that it was, in fact, the Americans who brought the virus to that place (Torreón, Coahuila) to later be spread around the country ${ }^{10}$. In 1951, the most severe outbreak of infantile paralysis in the history of the Federal District (today known as Mexico City) was registered, when 1002 cases, 547 male and 455 female, occurred, with the most affected population group being those between 1 and 5 years of age who lived in poor conditions, were malnourished, lived in the most unhealthy neighborhoods of the city and with a higher than average population density ${ }^{11}$.

With this poliomyelitis outbreak, the Health and Assistance authorities increased their activities, establishing epidemiological services, hospitals, and outpatient clinics dedicated specifically to the attention of the problem. In light of the emergency, both the National Campaign Against Polio and the National Committee of Study Against Poliomyelitis was created, which comprehended the three main aspects of the problem: (1) research and epidemiological control; (2) scientific research, and (3) technical and assistance research. The committee was formed by Dr. Carlos Calderón, Dr. Luis Vázquez Campos, Dr. Gerardo Varela, Dr. Fernando López Clares and orthopedists Dr. Juan Farill and Dr. Alejandro Velasco Zimbrón.

Part of the Committee's job consisted of applying the necessary measures to try to limit the spread of paralytic cases, such as (1) staying away from crowds and very specifically children under 5 years of age, and (2) avoid taking children under 5 years old to children's parks, markets, movie theaters, theaters, pools, and churches. The ideal would be for children to only have contact with their parents, brothers, and children with whom they play every day, and not allowing them to have any contact with strangers to this circle during June to September, the time with the highest registry of paralytic cases. (3) Likewise, the recommendation was to delay surgical interventions of the throat and dental extractions in children under 5 years of age. (4) Keep children under 10 years of age from enduring physical, mental, or emotional fatigue. (5) Dress them adequately, keep them from suffering drastic changes in temperature and feed them as well as possible with a diet based on fruits, vegetables, milk, bread, and eggs. (6) During June to September, be thorough in cleaning the rooms where children sleep, play, eat, and keep the place free of flies (it was believed that these insects transmitted the disease). (7) Every child who presented fever, even if it was a mild one, was immediately put into bed, and a physician would be called for their evaluation, and (8) Avoid unnecessary travel to other places, especially with children, and eliminate travel to places where there was a paralytic polio epidemic. Given these recommendations by the Committee with the support of the Secretary of Health and Assistance, there were severe polio outbreaks like those which occurred in 1951 with 1834 cases, 1953 with 1787, and 1955 with 1824 cases, before the emergence of the first injectable anti-poliomyelitic vaccine by Jonas Salk in 1955 and an oral one by Albert Bruce Sabin in 1962, whose vaccine would be incorporated into sugar cubes or orange juice for children, though the doses were variable.

The last case occurred on October 18, 1990. The patient was Luis Miguel Valencia Castellanos, who was born on September 26, 1989, in a ranch from the municipality of Culiacan Sinaloa, who emigrated with his family months later to the rural coastal population of "José María Morelos" in the town of Tomatlan, Jalisco, and at 13 months of age fell victim to this disease ${ }^{12}$.

\section{Restarting the march. Orthopedic braces for polio sequelae}

These polioviruses (mainly type I) cause injuries in the spinal cord's motoneurons, resulting in a natural infection and later asymmetric flaccid paralysis, with a preferent affectation of the muscles closer to the root of the limbs. In general, $25 \%$ of patients completely recovered, another $25 \%$ remained with muscular weakness, and $50 \%$ remained with permanent sequelae. In this regard, we ask ourselves, what did Mexican orthopedists do facing the poliomyelitis pandemic? How did 
they treat the paralysis and sequelae of the disease? These are dilemmas that are addressed hereunder.

Children who had their respiratory muscles paralyzed had to be assisted. Otherwise, they would choke. Therefore, they were put into machines commonly known as steel lungs or Emerson-type pulmotors (a machine which allowed a person to breathe when they lost control of the respiratory muscles, invented in 1928 by Philip Drinker, a medical engineer at Harvard). With the vaccination against polio programs and the arrival of modern ventilators, which controlled respiration through intubation of the airways, the use of the steel lung disappeared. After preventing asphyxiation, the next step was to manage sequelae. That is when the orthopedist appears, who were the first physicians preoccupied with treating the musculoskeletal sequelae that would almost always end up in deformities or surgical resolution, starting with them the specialty of rehabilitation ${ }^{13}$ in almost every country ${ }^{14}$.

To this end, the orthopedist must have full knowledge of the illness to be able to apply, with the help of other specialists (pediatricians, neurologists, and psychiatrists) the treatment which these patients affected by poliomyelitis must undergo and rehabilitate as completely and as soon as possible, in their physical aspect as well as psychological. That is, assure people with disabilities the same opportunities to live in their community as participant members. To that end, it was necessary to provide the means and services which would allow them to obtain the maximum degree of physical, economic, and social independence ${ }^{15}$. Thus, hospitals and functional orthopedic readaptation centers were created. With the slogan "if the deformity cannot be avoided, it ought to be corrected ${ }^{16}$," the orthopedist helps people who have restrictions in some fundamental movements of the body.

They specialize in correcting defects of the spinal column (scoliosis), deformities in the legs and arms, and products of paralysis through surgery or with the help of orthopedic devices, as well as education on the value of resting and balance of the muscles, with which they isolated musculoskeletal illnesses from general medicine for the $1^{\text {st }}$ time, setting the foundations of today's orthopedics, which addresses prevention, diagnosis, and treatment of diseases of the musculoskeletal system.

Poliomyelitis cooperated in the change of the structure in the medical profession. It contributed to the impulse and development of orthopedics in Mexico (especially in the sub-branch of pediatric orthopedics). The specialty had begun in the years before but gained traction due to the possibility that orthopedists had to have a personified ally among children affected by this disease. Polio added to those victims of occupational accidents to constitute a group of bodies over which orthopedists could improve their techniques and showcase their ability to correct deformities and return function to affected anatomical parts.

We must take into consideration that the arrival of the disease to Mexico occurred at a time where the level of domestic sanitary organization was experiencing significant institutional changes and coincided with the time when several Mexican physicians were studying (between 1940 and 1950) the specialty of orthopedics in hospitals around the United States. Scientific exchange trips were an opportunity to know centers, treatment paths, and technological innovations that would later be implemented in their country of origin ${ }^{17}$. Such are the cases of Dr. Everardo Gustavo Lozano, who completed his specialty in Traumatology and Orthopedics at the University of lowa, under the tutelage of the prestigious Austrian orthopedist Arthur Steindler, Dr. Luis Jorge Santoscoy Gómez, who traveled abroad to complete a Fellow (a research position at a university or institution) at the Jefferson Davis Hospital at the Baylor University in Houston, Texas ${ }^{18}$ and Dr. Eduardo Luque Rebollar, who completed his residency at the Princess Elizabeth Royal Orthopedic Hospital in Devon \& Dexeter, England. His experience in treating children with paralytic scoliosis secondary to poliomyelitis led him to search for a fixation method to efficiently correct the deformity, allowing the development of the spinal cord with an adequate cardiopulmonary function without the need of an external fixation device (corset) ${ }^{19}$.

The history of orthopedics shows as its main characteristic the effort to develop all kinds of instruments to correct deformities. An engraving of a crooked tree tied with a stick became the symbol of orthopedic surgery after appearing in the book by Nicholas Andry de Boisregard (1741) titled: Orthopedics: the art of correcting and preventing deformities in children by methods which may be easily applied by their parents and those in charge of the education of children. The Andry tree represents the correction of a crooked tree using an incipient "orthopedic device" that serves as a guide, a support, performs immobilization in benefit of evolution and treatment, and helps the man resist gravity's action to remain erect ${ }^{20}$.

They have given the name of "orthopedic apparatus" to mechanical devices made of different materials (metal or plastic) whose objective is to protect weak muscles, maintain normal alignment of the joints and bone 
segments, prevent deformations, facilitate functions of the musculoskeletal system, and substitute for any missing parts ${ }^{21}$. These last ones constitute what is known as prothesis ${ }^{22}$, and the other is part of what is called orthosis ${ }^{23}$. Fundamental objectives of orthopedic devices are:

1) Prevent deformities

2) Correct or reduce deformities and

3) Facilitate or allow functions ${ }^{20}$.

According to orthopedists Luis Sierra Rojas and Alfonso Tohen Zamudio, the devices which are applied for the treatment of poliomyelitis patients are divided into three categories:

1) Deformities, protection, and prevention devices.

2) Corrective devices and

3)Functional devices ${ }^{24}$ (Fig. 1).

Just as the name indicates, the first category places the joints involved into a neutral position and are generally for resting. There are metallic frames, cushioned metallic grooves, wooden grooves, support boards or wooden supports, metal splints, and devices made of different materials such as plastic, plaster, and cloth (Fig. 2).

Corrective devices are protective devices with modifications, and their objective is to cooperate to suppress incipient deformities in soft tissues caused by a muscular imbalance. The most common ones were made of plaster; although some were made of metal, the latter were expensive and hard to get. With the rise of polypropylene (the plastic that emerged in 1907), fiberglass and titanium, people could manufacture lighter, stronger, more resistant devices at a lower cost (Fig. 3).

The third category is formed by functional devices, which represented the most complicated problem in the manufacture and adaptation mechanics, since they needed to meet different requirements related to the mechanics of musculoskeletal physiology (ability to perform coordinated movements) ${ }^{24}$, requirements that were only in the reach of highly trained orthopedists, given their ample knowledge of the human anatomy. In the elaboration of these devices, the orthopedist, overseeing their fabrication, in his element seeks to meet the basic aspects of every device:

1) Postural alignment of the body.

2) Maximum preservation of musculoskeletal function.

3)Preventing the development of deformities.

4) Reestablishing stability of the body.

5)Lightness to avoid an overload of weakened muscles and

6) Substituting for the non-recovered function ${ }^{24}$.

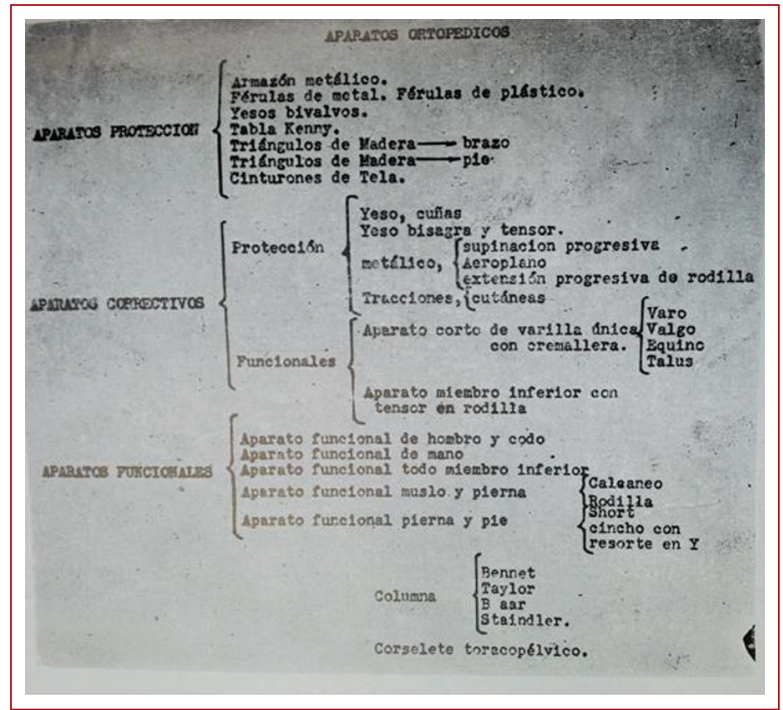

Figure 1. Types of orthopedic devices. Source. Alfonso Tohen Zamudio, Physical therapy, p.92.

At first, the objective of functional devices was to allow the patient to have a more active life, but there was no special attention placed on the need for these to help recover the affected segment. Every orthopedic device, including those of the functional type, ought to have muscular reeducation elements ideal for every type of treatment of a paralyzed muscle (Fig. 4).

Mexican orthopedists such as Alfonso Tohen Zamudio, Luis Sierra Rojas, and Alejandro Velasco Zimbrón, among others, fabricated and adapted a great number of surgical devices in patients with poliomyelitis sequelae at their respective hospitals and rehabilitation centers: metallic splints, cloth belts, circular plaster devices, Phelp-type devices, cervical devices, dorsal and lumbar devices, devices with pelvic and bilateral belts and/or with pelvic thoracic corsets, traction, correction and contention devices, devices with ischiatic seat devices to eliminate the weight of the body, ankle, and knee hinges or joints in their five modalities: (1) free, (2) fixed, (3) with 20 degrees mobility, (4) with free extension and plantar flexion at zero degrees, and (5) with free plantar flexion and extension at zero degrees. Single bar devices with plantar flexion stop at 90 degrees with the addition of external or internal belts and were destined for neck and trunk deformities as well as for lower and upper limbs, of which the latter were most utilized (Fig. 5).

For upper limb deformations, the most recommended device was the airplane-type splint manufactured by Warm Spring ${ }^{25}$ in the USA. It was recommended for 


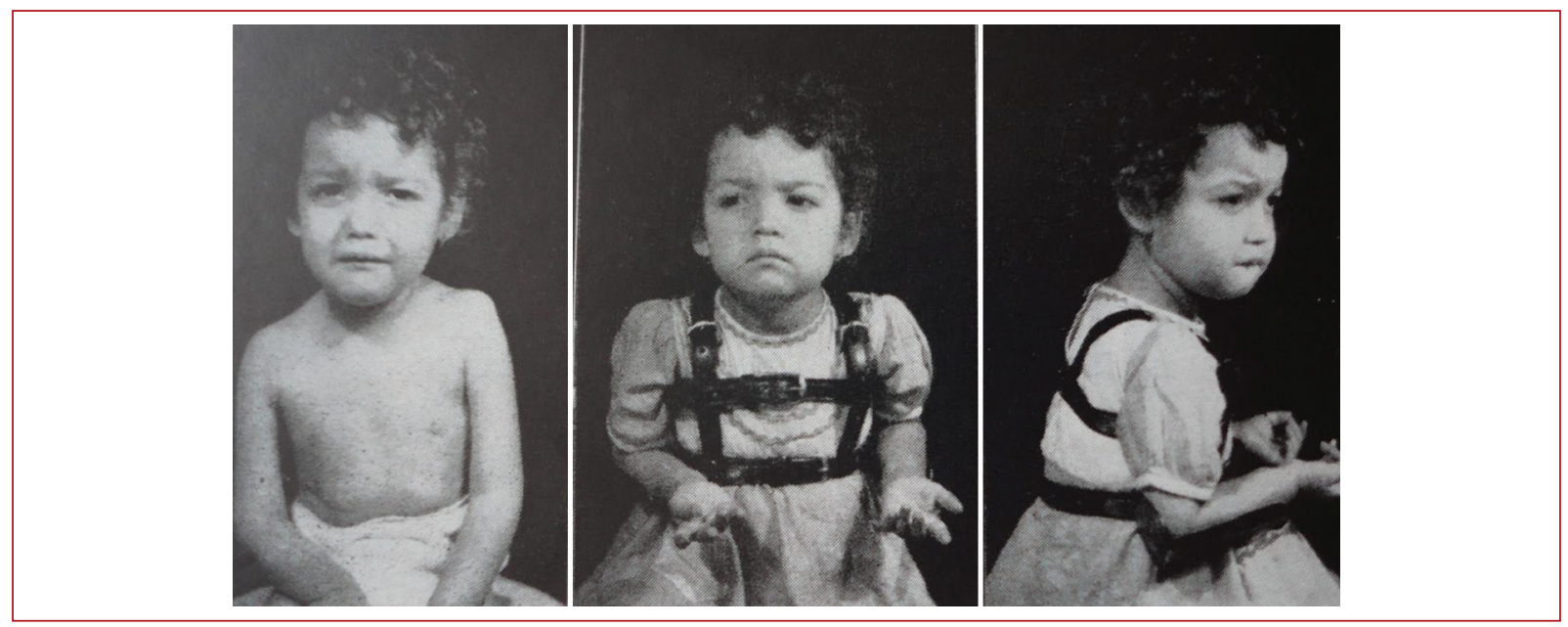

Figure 2. Abduction device by orthopedist Juan Farill. Source. Leonardo Zamudio Villanueva, Orthopedic devices and shoes guide, p.59.



Figure 3. Corrective device. Device devised by Luis Sierra Rojas and Alfonso Tohen Zamudio in the Children's Hospital of Mexico "Federico Gómez" for the deformation of the forearm. Source: Luis Sierra Rojas and Alfonso Tohen Zamudio, Aparatos ortopédicos en el tratamiento de la poliomielitis, p. 10.

problems of the orthopedic type such as fractures, dislocations, nerve injuries, and paralysis of the deltoid and biceps in patients with polio during the convalescent stage. It was utilized horizontally or vertically, depending on the degree of paralysis. The problem with the device is that it turned out to be voluminous, bulky, and heavy, characteristics made obvious when the patient was dressing up or preparing for bed.

Dr. Tohen Zamudio, taking advantage of his vast knowledge and intelligence, solved these issues by coming up with an idea for a device that consisted of

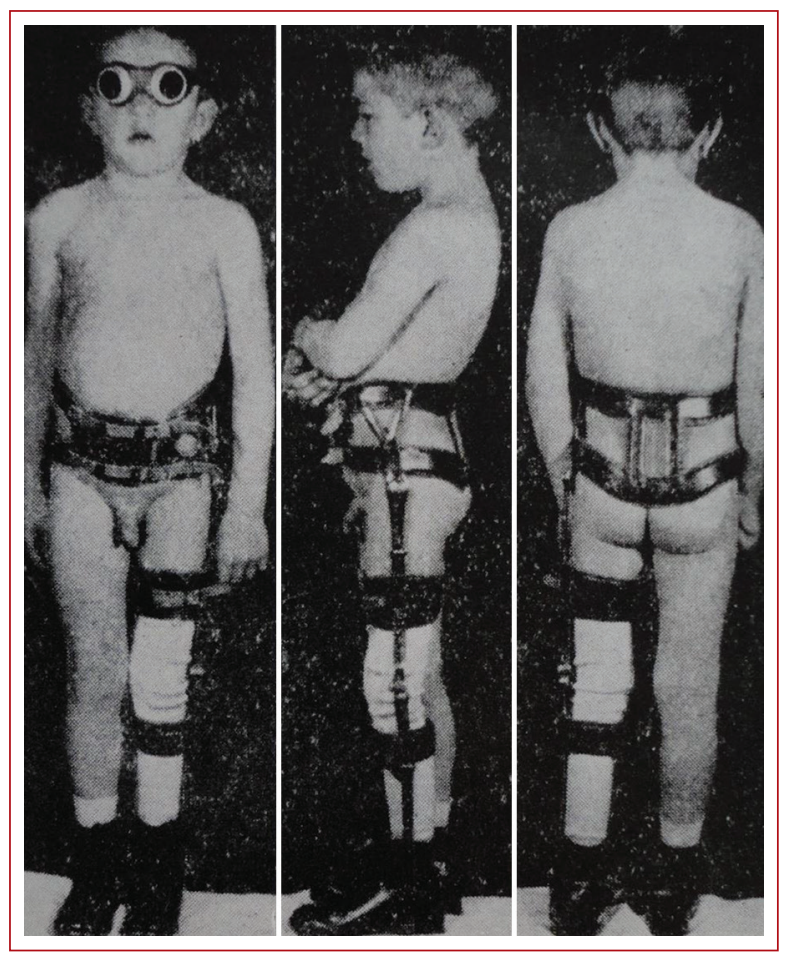

Figure 4. Double band appliance for weakness in the gluteus medius. Source: Luis Sierra Rojas and Alfonso Tohen Zamudio, Aparatos ortopédicos en el tratamiento de la poliomielitis, p. 26.

an elbow splint that came up to the forearm and placed the shoulder in a 20-degree abduction and the elbow at a 90-degree flexion. The splint was made of aluminum and leather and was attached to the torso with belts. Some of its advantages included that it was small 


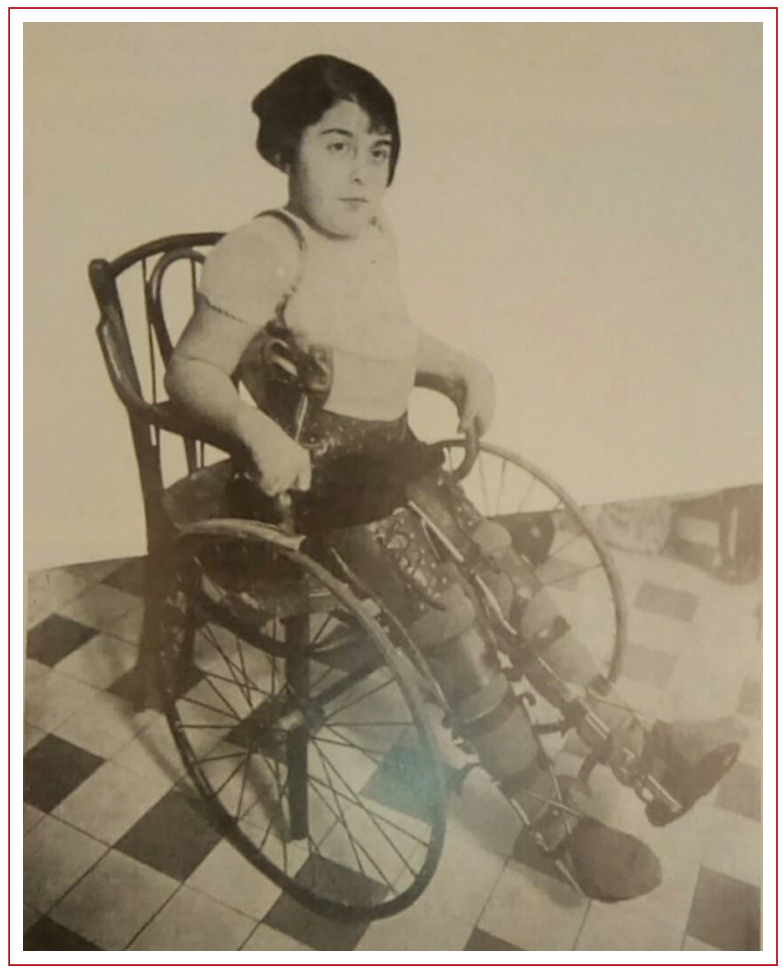

Figure 5. Orthopedic appliance for lower extremities. Source: Dr. V.L. Ferrándiz, Poliomielitis (Parálisis Infantil), p. 159.

and light. It did not collide with the torso, allowing for a more functional position for the shoulder and elbow joints and facilitating voluntary joint mobility ${ }^{26}$.

In paralysis, especially as a result of poliomyelitis, other devices were used like the splint on " 8 " splint, which was also used in fractures of the clavicle, or the device for the paralysis of the superior serratus muscle paralysis (a muscle located in the superior lateral face of the thorax). Another device, often utilized in Erb's palsy (loss of movement or weakening of the arm, which occurs when there is damage to the conjoint of nerves surrounding the shoulder) was the "fencing splint" that maintained the arm in abduction and external rotation, the elbow in flexion and the forearm in supine.

For neck rigidity, the use of a cotton collar was recommendable and was especially useful in the early stages of poliomyelitis, where physical rest of the cervical muscles is convenient. For the back, the use of Taylor's spinal device, which consists of a pelvic ring with two padded studs and shoulder straps, was of great help. Support for the arms and head was added when/if necessary. A Bennet-Kendall device was used for the hip; a corset adapted to the torso connected

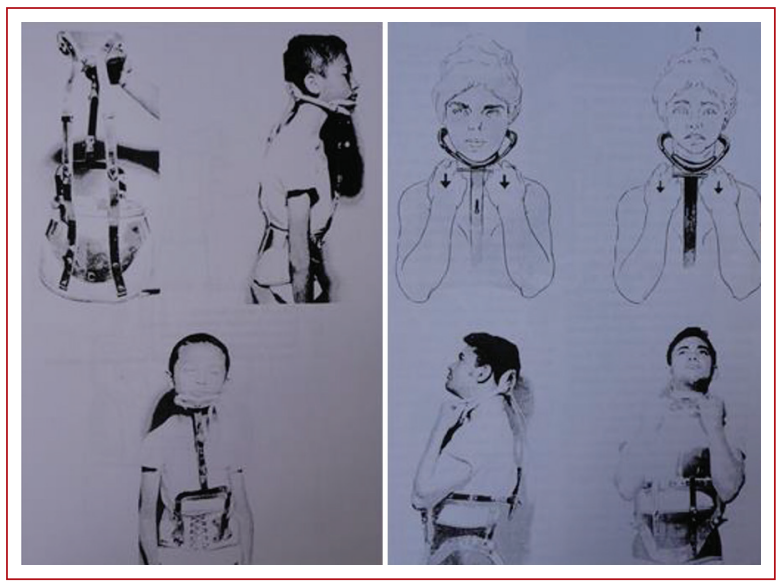

Figure 6. Milwaukee appliance for scoliosis (left) and its modification by orthopedist Alfonso Tohen Zamudio (right). Source: Alfonso Tohen Zamudio, Manual de ortopedia mecánica, p. 132 and 141.

with one piece to the waist, which was useful to avoid cases of hip luxation consecutive to paralysis of the muscles of the buttocks ${ }^{27}$.

For cases of paralytic scoliosis, the Steindler device, the Hoke corset, the Bennet-Kendall device, and the Milwaukee device (Fig. 6) provided proper support and protection to this part of the body to prevent permanent scoliosis. The Milwaukee device was the one with the highest acceptance among orthopedists for medical treatment of scoliosis, even though it had the defect of causing deformities in the lower jaw since it compressed the patients' jaw for almost the entirety of the time, which was sometimes difficult to be corrected by the orthodontist ${ }^{20}$. Dr. Alfonso Tohen Zamudio modified the Milwaukee device by adding a transversal bar which allowed the patient to lift their lower jaw without the need to support it for a long time in the bar, thus avoiding deformity.

\section{Conclusions}

In the majority of temporary or permanent muscular paralysis, the adaptation process to the orthopedic device lasts for most of the patients' life, since these were used positively by placing weak muscles in rest, and protecting them, preventing deformities, and correcting them, all of this aimed to maintain the musculoskeletal system in the best conditions to reach the maximum recovery possible $^{21}$. In other cases, the patient had to undergo a series of surgeries ranging from 3 to 15 surgeries, while others recovered enough muscle capability to dispense with the device or surgery. In each case, orthopedic devices 
accomplished their purposes, that is, to keep the legs and other parts of the body in useful positions.

We live in a globalized world and if there is a country where a wild virus causes poliomyelitis cases, it could arrive at this country at one point or another. In that sense, we cannot state that polio will not return to the country or to any country in the world where it has been eliminated if cases continue to appear in other places like Pakistan or Afghanistan, where the disease has not been completely eradicated. On the other hand, the World Health Organization (WHO) declared Africa free of the disease, thanks to vaccination campaigns that have taken place on the continent, considerably reducing cases. The last case of wild poliovirus detected in Africa was in the northeast of Nigeria in 2016, and after 4 years, there have been no other cases. Poliomyelitis cannot be cured by any pharmacological treatment; it is only possible to prevent it and eradicate it through campaigns and vaccination; that is the only way to end this disease.

\section{Acknowledgments}

The author thanks Dr. Carlos Agustín Rodríguez-Paz for his comments and suggestions for the improvement of this text, as well as for providing the material.

\section{Conflict of interest}

The author declares that they do not have any conflicts of interest.

\section{Funding}

The present research did not receive any financing and/or economic gratification.

\section{Ethical disclosures}

Protection of human and animal subjects. The authors declare that no experiments were performed on humans or animals for this study.

Confidentiality of data. The authors declare that they have followed the protocols of their work center on the publication of patient data.

Right to privacy and informed consent. The authors declare that no patient data appear in this article.

\section{References}

1. Ferrandiz VL. Poliomielitis (Parálisis Infantil). Barcelona: Ediciones Cedel; 1971.

2. Brunetti C. La Reacción de Los Bebés a la Vacuna Para la Gripe. Muy Fitness. United States: Leaf Group Ltd.; 2020. Available from: http://www. ehowenespanol.com/diferentes-cepas-del-virus-poliomielitis-sobre_526079. [Last accessed on 2020 Nov 23].

3. Rang M. The Story of Orthopaedics. Estados Unidos: Saunders Company; 2000.

4. Merrill R. Introduction to Epidemiology. Estados Unidos: Jones and Bartlett Publishers; 2010.

5. Álvarez Alva R. Epidemiología de la poliomielitis. Bolet Méd Inst Mex Seguro Soc. 1959;1:5.

6. Testa DE. Curing by doing: la poliomielitis y el surgimiento de la terapia ocupacional en Argentina, 1956-1959. Manguin Hist Ciên Saúde. 2013;20:1572

7. Alarcón AG. Poliomielitis anterior aguda. Parálisis infantil. Estudio estadístico, epidemiológico, clínico, profiláctico y terapéutico. Las epidemias del mal en México. Med Rev Mex. 1951;31:23

8. Amezquita JA, Bustamante ME, Picazoz AL, Fernández del Castillo F. Historia de la Salubridad y de la Asistencia en México. México: Secretaría de Salubridad y Asistencia; 1960.

9. Del Villar AM, Márquez Morfín L. Patricia Pardo C. El Miedo a Morir. Endemias, Epidemias y Pandemias en México: análisis de larga duración. México: Centro de Investigaciones y Estudios Superiores en Antropología Social, Instituto de Investigaciones Dr. José María Luis Mora, Benemérita Universidad Autónoma de Puebla; 2013.

10. La poliomielitis vino de los Estados Unidos. El Siglo de Torreón. Miércoles 25 de Agosto de. Estados Unidos: La poliomielitis vino de los Estados Unidos; 1948.

11. Argil G, Pintado R, Hernández AO. Fondo: subsecretaría de Salubridad. Parálisis Infantil (polio). Consideraciones Epidemiológicas Sobre Los Brotes de Polio en México en Los Años de 1950-1951. Spain: Archivo Histórico "Rómulo Velasco Ceballos". Secretaría de Salud; 1963.

12. González-Rubio R. La poliomielitis y su erradicación en México y las Américas reto histórico de salud hecho realidad. Rev Méd Cient Secret Salud Jalisco. 2018;5:49-51.

13. La medicina de rehabilitación es el conjunto de técnicas y métodos que sirven para recuperar una función o actividad del cuerpo que ha disminuido o se ha perdido a causa de un accidente o de una enfermedad. Invalidez y rehabilitación. Mesa redonda. Rev Facult Med. 1975;18:6.

14. Sotelano F. Historia de la rehabilitación en latinoamérica. Am J Phys Med Rehabil. 2012;91:2.

15. Guillermo Ibarra L. Tratamiento integral del niño inválido. Ecos Med Física Rehabil. 1984;6:13.

16. Lewin P. Parálisis Infantil. Poliomielitis Anterior. Barcelona España: Salvat/Facultad de Medicina de la Universidad North Western; 1945.

17. Edelvis Testa D. Curing by doing: la poliomielitis y el surgimiento de la terapia ocupacional en Argentina, 1956-1959. Manguin Hist Ciên Saúde. 2013;20:1576

18. Carrillo Pérez J. Profesor luis jorge santoscoy gómez. Ortho Tips. 2009;5:203

19. Luque E. Rebollar. Ortho Tips. 2005;1:70

20. Tohen Zamudio A. Manual de Ortopedia Mecánica. Ciudad de México: Alfonso Tohen Zamudio; 1970.

21. Rojas LL, Tohen Zamudio A. Aparatos ortopédicos en el tratamiento de la poliomielitis. Bolet Méd Hosp Infant Méx. 1953;10:128.

22. Tohen Zamudio A. Prótesis (del latín Prothesis) es el procedimiento por medio de la cual se trata de sustituir artificialmente la falta de un órgano o parte de è. In: Cuando un Aparato Sustituye Una de Las Extremidades Recibe el Nombre de Miembro Artificial. Manual de ortopedia mecánica. Ciudad de México: Hospital Infantil de México; 1979.

23. Zamudio L. Manual de Zapatos y Aparatos Ortopédicos. Ciudad de México: La Prensa Médica Mexicana; 1983.

24. Rojas LL, Zamudio AT. Aparatos ortopédicos en el tratamiento de la poliomielitis. Bolet Méd Hosp Infant Méx. 1953:10:129-30.

25. Rogers Naomi. Polio Chronicles: Warm Springs and Disability Politics in the 1930s. Asclepio. Revista de Historia de la Medicina y de la Ciencia. 2009;61(1):143-174.

26. Rojas L, Zamudio AT. Aparatos ortopédicos en el tratamiento de la poliomielitis. Bolet Méd Hosp Infant Méx. 1953;10:8.

27. Zamudio AT. Manual de Ortopedia Mecánica. Ciudad de México: Alfonso Tohen Zamudio; 1970. 